\title{
PENGARUH INFUSA DAUN SIRSAK (Annona muricata L.) TERHADAP PENURUNAN KADAR KOLESTEROL MENCIT JANTAN (Mus musculus) GALUR SWISS WEBSTER
}

\author{
Rheima Indriani Iskandar, Nuri Handayani, Tovani Sri
}

\begin{abstract}
ABSTRAK
Kolesterol bemanfaat bagi tubuh pada kadar normal tetapi jika berlebihan dapat mengancam kesehatan. Sirsak merupakan salah satu tanaman yang dapat digunakan untuk menurunkan kadar kolesterol. Penelitian ini bertujuan untuk mengetahui pengaruh infusa daun sirsak untuk menurunkan kadar kolesterol mencit putih jantan galur swiss webster dan dosis infusa daun sirsak yang paling efektif dalam menurunkan kadar kolesterol.

Penelitian ini merupakan studi eksperimental dengan menggunakan 15 ekor mencit jantan galur swiss webster yang dibagi tiga kelompok secara acak, dosis I 520 mg/kg BB, dosis II 910 $\mathrm{mg} / \mathrm{kg} \mathrm{BB}$, dan dosis III $1.690 \mathrm{mg} / \mathrm{kg}$ BB. Kadar kolesterol mencit diukur setelah perlakuan selama 7 hari.

Hasil dari penelitian menunjukkan infusa daun sirsak dosis $520 \mathrm{mg} / \mathrm{kg} \mathrm{BB} \mathrm{,} 910 \mathrm{mg} / \mathrm{kg} \mathrm{BB}$, $1.690 \mathrm{mg} / \mathrm{kgBB}$ menurunkan kolesterol sebesar $125 \mathrm{mg} / \mathrm{dL}, 93 \mathrm{mg} / \mathrm{dL}$ dan 92,33 mg/dL . berdasarkan uji T didapatkan adanya perbedaan signifikan penurunan kolesterol pada dosis 910 $\mathrm{mg} / \mathrm{kg}$ BB dan $1.690 \mathrm{mg} / \mathrm{kgBB}$. Sedangkan pada dosis $520 \mathrm{mg} / \mathrm{kgBB}$ tidak ada perbedaan signifikan. Namun, jika dilihat dari penurunan rata-rata dosis 520 mg/kgBB menunjukan penurunan terbaik. Perlu penelitian lanjut mengenai kolesterol mana (HDL,LDL,atau VLDL) yang paling berpengaruh terhadap pemberian infusa daun sirsak dengan dosis yang lebih bervariasi.
\end{abstract}

Kata Kunci : Infusa daun sirsak, kadar kolesterol, Uji T

\section{ABSTRACT}

Cholesterol is beneficial both to the body when at a normal level and the higher cholesterol in the body, the greater danger that threatens the health of the body. This study aimed to determine the effect of sirsak (Annona murcata L.) leaf infusion to decrease total blood cholesterol level of male mice model swiss webster and to know the most effective dose of giving sirsak (Annona muricata L.) .

The research was laboratory experimental using 15 male mices model swiss webster were divided randomly into three groups. First blood total cholesterol level of mices was measured then treatment with hypercholesterolemia during 7 days. After hypercholesterol, three groups mices was treatment with Sirsak (Annona muricata L.) infuse with dose 520; 910; and $1.690 \mathrm{mg} / \mathrm{kgBB}$. Total blood cholesterol level was measured after one week, 
The study showed dose 520; 910; and $1.690 \mathrm{mg} / \mathrm{kgBB}$ lower cholesterol amounting to 125; 93; and $92,33 \mathrm{mg} / \mathrm{dL}$. Dependent $\mathrm{T}$ test shows that there is a significant difference in lowering cholesterol in a dose $910 \mathrm{mg} / \mathrm{kg} \mathrm{BB}$ and $1.690 \mathrm{mg} / \mathrm{kg} \mathrm{BB}$. While in a dose $520 \mathrm{mg} / \mathrm{kg}$ BB there is no significant difference but if it's seen from average lowering, dose $520 \mathrm{mg} / \mathrm{kg} \mathrm{BB}$ show the best result.

Key Word : Infusion leaf sirsak, cholesterol levels, T test

\section{PENDAHULUAN}

Kadar kolesterol yang tinggi dapat menyebabkan aterosklerosis yaitu penyempitan pada pembuluh darah arteri yang dapat terjadi karena adanya penumpukan kolesterol atau protein lain yang berasal dari makanan yang masuk ke dalam tubuh. Penumpukan ini juga menyebabkan pembuluh darah menjadi kaku (Sutanto, 2010). Penurunan kadar kolesterol dapat dilakukan dengan obat-obatan antihiperlipidemia. Namun, obat dari bahan alam pada saat ini banyak diminati oleh masyarakat dan menjadi pilihan lain selain terapi dengan obat-obat medis.

Sirsak (Annona muricata L.) merupakan tanaman tropis, termasuk kedalam keluarga Annonaceae merupakan tumbuhan berbunga, dengan sekitar 2300 sampai 2500 spesies dan lebih dari 130 genus (Kedari et al., 2014). Daging buahnya berwarna putih susu, rasanya manis asam dan berbiji kecil. Sirsak lebih dikenal sebagai tanaman buah. Namun, seiring dengan penelitian terhadap tanaman tersebut, kini populer sebagai tanaman obat. Berbagai penelitian menunjukan bahwa tanaman sirsak mengandung banyak khasiat untuk kesehatan. Bagian tanaman sirsak, mulai dari daun, bunga, buah, biji, akar, sampai kulit batang dan akarnya dapat dimanfaatkan sebagai obat (Mardina, 2011 dalam Uneputty et al., 2013)

Secara empiris daun sirsak telah digunakan masyarakat untuk menurunkan kolesterol. biasanya cara yang digunakan di masyarakat yaitu sebanyak 3-5 lembar daun sirsak sehari direbus dalam 3 gelas air hingga tersisa 1 gelas kemudian diminum (Redaksi Trubus, 2012 dalam Uneputty et al., 2013). Untuk memastikan hal terbut perlu diketahui secara pasti apakah ada pengaruh pemberian infusa daun sirsak (Annona muricata L.) dalam menurunkan kadar kolesterol dan Berapa dosis optimalnya dengan menggunakan hewan uji mencit (Mus musculus).

\section{METODE}

Metode yang digunakan dalam penelitian ini termasuk penelitian eksperimental (True Experiment Design) dengan rancangan penelitian randomized pretest and posttest. Alat yang digunakan dalam penelitian ini adalah kandang metabolik, gelas kimia, hot plate, gelas ukur, corong kaca, batang pengaduk, spuit, lanset, sonde oral, alat ukur kolesterol easy touch GCU 3in1, strip cek kolesterol easy touch GCU 3in1, timbangan elektronik, timbangan hewan, kertas saring, dan kapas. Bahan yang digunakan yaitu daun sirsak (Annona Muricata L.), aquades, pakan standar (BR II), dan pakan tinggi lemak. Variabel bebas yaitu dosis cairan infusa daun sirsak dan variabel tergantung yaitu kadar kolesterol mencit. 
Penelitian ini dibagi tiga kelompok yaitu kelompok $A$ sebagai kelompok mencit yang diberikan dosis 3 lembar daun sirsak, kelompok B yaitu kelompok mencit yang diberikan 5 lembar daun sirsak, dan Kelompok $\mathrm{C}$ yang diberikan 10 lembar daun sirsak. Jumlah sampel tiap kelompok terdiri dari 3 ekor mencit, sehingga didapatkan semua jumlahnya yaitu 15 ekor mencit. Pengambilan data pertama dimulai seminggu setelah mencit diinduksi kolesterol dan seminggu setelah pemberian infusa daun sirsak. Penelitian kali ini bersifat deskriptif. Simple random sampling digunakan dengan cara mengambil sampel dari suatu populasi secara acak.

Metode analisis data yang akan digunakan adalah uji T berpasangan untuk mengetahui perubahan kadar kolesterol pada setiap kelompok perlakuan.

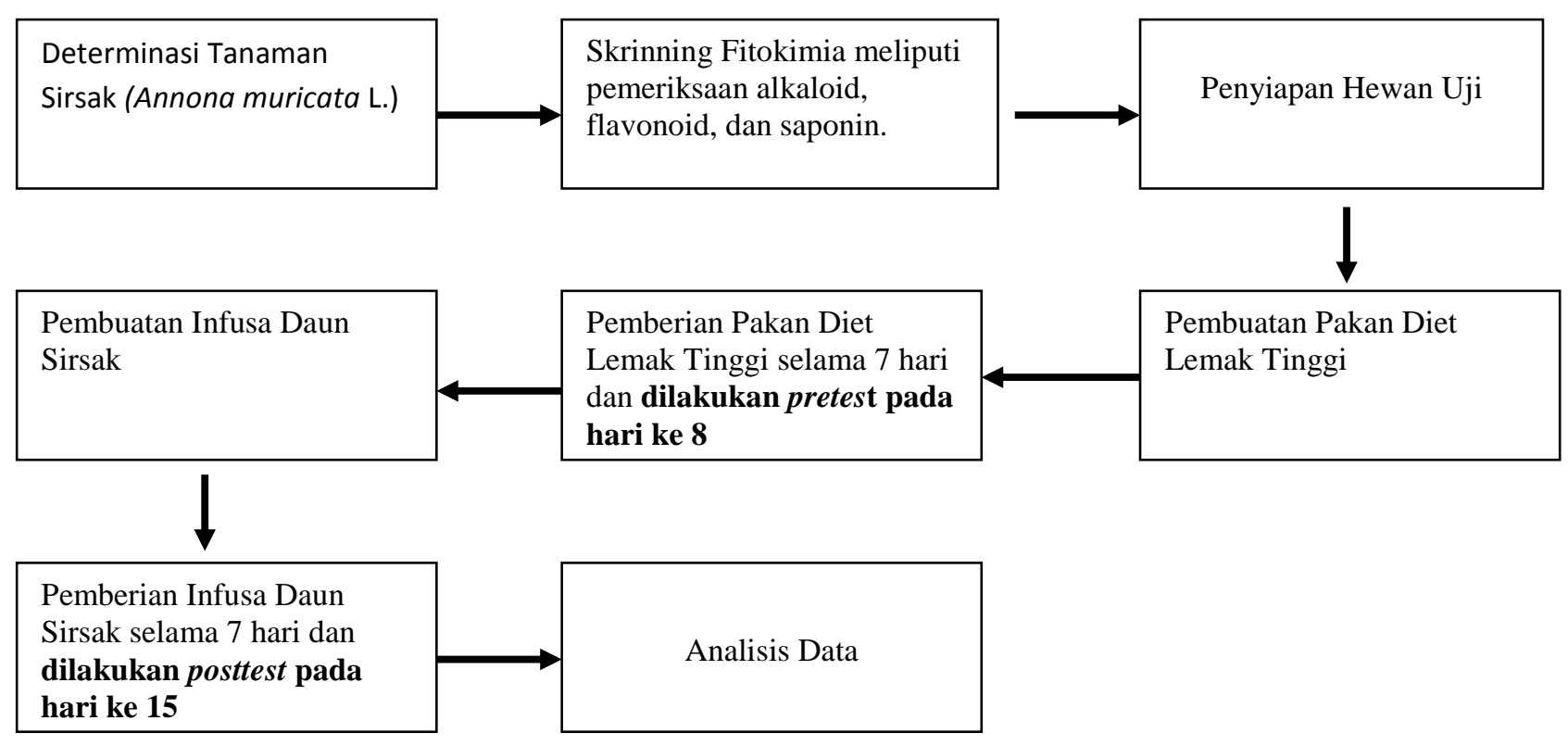

Gambar 1. Prosedur Pengambilan data

Determinasi tumbuhan dilakukan di laboratorium Herbarium Bandungense Sekolah IImu dan Teknologi Hayati, Insitut Teknologi Bandung.

\section{Skrining Fitokimia}

Skrinning Fitokimia yang dilakukan meliputi skrinning alkaloid, saponin, dan flavonoid.

a. Pemeriksaan golongan senyawa alkaloid Infusa ditambahkan dengan amonia encer lalu ditambahkan pereaksi mayer, lalu diamati ada tidaknya endapan berwarna putih.

b. Pemeriksaan golongan senyawa saponin Infusa dipindahkan kedalam tabung reaksi kemudian dikocok kuat-kuat selama beberapa menit, pembentukan busa sekurangnya setinggi $1 \mathrm{~cm}$ dan persisten selama beberapa menit dan tidak hilang dengan penambahan asam menunjukan adanya saponin.

c. Pemeriksaan golongan senyawa flavonoid 
Infusa ditambahkan serbuk Zn, larutan alkohol asam klorida (1:1) dan amil alkohol, kemudian campuran dikocok kuat-kuat, adanya flavonoid akan menyebabkan filtrat berwarna merah, kuning atau jingga yang dapat ditarik oleh amil alkohol.

d. Pemeriksaan golongan senyawa tanin

Infusa ditambahkan larutan gelatin $2 \%$, sehingga akan terbentuk endapan putih.

\section{Penyiapan hewan uji}

Sebelum dimulai penelitian, di lakukan adaptasi hewan uji dahulu selama seminggu agar mencit terbiasa dengan lingkungan laboratorium. Selama seminggu adaptasi tersebut mencit diberikan pakan standar berupa pelet BR II yang sudah umum digunakan sebagai pakan hewan.

\section{Pembuatan pakan tinggi lemak}

Komposisi dari pakan ini yaitu lemak sapi dan miyak kelapa dengan perbandingan lemak sapi : minyak goreng (5:1) Cara pembuatan pakan ini yaitu dengan memanaskan lemak sapi yang berupa padatan berwarna putih sampai mencair, panaskan sampai didapatkan $25 \mathrm{ml}$, setelah mencair, masih dalam keadaan panas tambahkan minyak goreng $5 \mathrm{ml}$ pelan-pelan sambil diaduk hingga homogen (Widyaningrum., 2015).

\section{Pemberian pakan tinggi lemak}

Pemberian Pakan diet lemak tinggi dilakukan selama seminggu sebagai penginduksi kenaikan kolesterol pada mencit, setelah itu dihari ke-8 akan dilakukan pengecekan kadar kolesterol mencit.

\section{Pembuatan infusa daun sirsak}

Infusa Daun sirsak dibuat dengan cara merebus masing-masing 3 lembar, 5 lembar, dan 10 lembar daun pada $100 \mathrm{ml}$ aquades selama 15 menit terhitung pada suhu 15 menit, setelah itu infusa disaring lalu ditambahkan aquades panas sampai $100 \mathrm{ml}$ (Uneputty et al., 2013).

\section{HASIL}

Tabel 1.Hasil Skrining Fitokimia Infusa Daun Sirsak

\begin{tabular}{ll}
\hline Metabolit Sekunder & Hasil \\
\hline Alkaloid & $(+)$ endapan putih \\
Flavonoid & $(+)$ larutan kuning kemerahan \\
Polifenol & $(+)$ hijau kehitaman / biru tua \\
Tanin & $(+)$ endapan putih \\
Saponin & $(-)$ tidak terdapat busa \\
\hline
\end{tabular}


Pemberian pakan diet tinggi lemak bertujuan untuk induksi kolesterol agar mencit menjadi hiperlipidemia. Sebelum diberikan pakan diet tinggi lemak, setiap hari mencit ditimbang terlebih dahulu untuk mengetahui jumlah pakan yang harus diberikan.

Tabel 2. Pemberian pakan tinggi lemak selama 7 hari

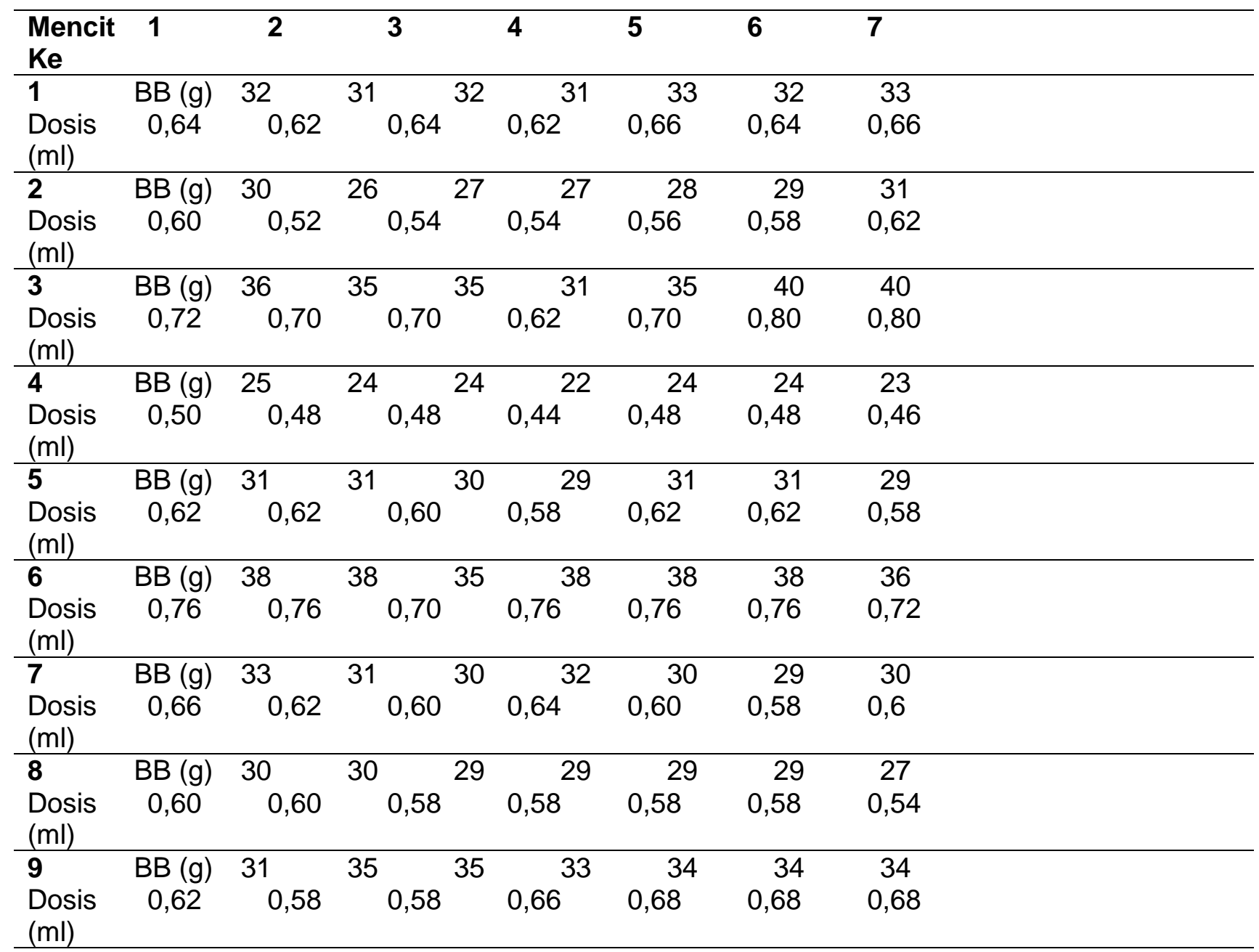

Setelah seminggu pemberian pakan, pada hari ke-8 mencit akan diambil darahnya dibagian ekor untuk dilakukan pengecekan kadar kolesterol dengan menggunakan alat easy touch GCU $\operatorname{3in} 1$, berikut tabel hasil pengukurannya.

Tabel 3. Kadar kolesterol setelah pemberian diet tinggi lemak

\begin{tabular}{cc}
\hline Mencit Ke & Kadar kolesterol setelah induksi kolesterol \\
\hline 1 & $381 \mathrm{mg} / \mathrm{dl}$ \\
2 & $172 \mathrm{mg} / \mathrm{dl}$ \\
3 & $203 \mathrm{mg} / \mathrm{dl}$ \\
4 & $282 \mathrm{mg} / \mathrm{dl}$ \\
5 & $168 \mathrm{mg} / \mathrm{dl}$ \\
6 & $182 \mathrm{mg} / \mathrm{dl}$
\end{tabular}


Infusa daun sirsak dibuat baru setiap hari, diberikan pada mencit pada hari ke-8 sampai hari ke-14. Untuk pemberian infusa daun sirsak pada mencit diperlukan konversi dosis terlebih dahulu,

\section{Tabel 4. Dosis 3 kelompok hewan uji}

\begin{tabular}{ccc}
\hline Nama Kelompok & Kelompok Uji & Perlakuan \\
\hline Kelompok A & Dosis infusa 3 lembar & Infusa Daun sirsak $520 \mathrm{mg} / \mathrm{kg} \mathrm{BB} / \mathrm{hari}$ \\
Kelompok B & Dosis infusa 5 lembar & Infusa Daun sirsak $910 \mathrm{mg} / \mathrm{kg} \mathrm{BB/hari}$ \\
Kelompok C & Dosis infusa 10 lembar & Infusa daun sirsak $1.690 \mathrm{mg} / \mathrm{kg} \mathrm{BB/hari}$ \\
\hline
\end{tabular}

Hasil rata-rata perubahan kadar kolesterol darah mencit sebelum diberikan perlakuan pemberian infusa daun sirsak dan sesudah diberikan perlakuan pemberian infusa daun sirsak selama seminggu.

Tabel 5. Kadar kolesterol sebelum dan setelah perlakuan

\begin{tabular}{lcc}
\hline \multirow{2}{*}{ Kelompok } & \multicolumn{2}{c}{ Kadar Koleterol total (mg/dL) } \\
\cline { 2 - 3 } & Sebelum perlakuan (H-0) & Setelah Perlakuan (H-8) \\
\hline Kelompok A ( dosis I) & 252,00 & 127,00 \\
Kelompok B (dosis II) & 210,66 & 117,66 \\
Kelompok C (dosis III) & 211,33 & 119,00 \\
\hline
\end{tabular}

\section{Keterangan :}

- Dosis I = infusa daun sirsakdengan dosis $520 \mathrm{mg} / \mathrm{kg} \mathrm{BB}$

- Dosis II= infusa daun sirsakdengan dosis $910 \mathrm{mg} / \mathrm{kg} \mathrm{BB}$

- Dosis III= infusa daun sirsak dengan dosis $1.690 \mathrm{mg} / \mathrm{kg} \mathrm{BB}$

Data pengukuran kolesterol di uji t berpasangan (Paired-Samples T Test) dengan derajat kepercayaan 95\% ( $p<0,05)$. Data kolesterol yang dianalisis yaitu data perlakuan sebelum pemberian perlakuan dan data setelah pemberian perlakuan, tujuannya untuk mengetahui bermakna atau tidaknya perubahan kadar kolesterol pada masing-masing kelompok setelah 7 hari perlakuan.

Tabel 6. Hasil Uji $\boldsymbol{t}$ ( Paired-Samples T Tast) kadar Kolesterol pada Mencit Jantan

$\begin{array}{cccc}\text { Kelompok } & \text { Kelompok A (Dosis I) } & \text { Kelompok B (Dosis II) } & \text { Kelompok C (Dosis III) } \\ & \text { sesudah perlakuan } & \text { sesudah perlakuan } & \text { sesudah Perlakuan }\end{array}$


Kelompok A (Dosis I)

Kelompok B (Dosis II)

Kelompok C (Dosis III)

\subsection{9}

0,04

Berdasarkan tabel 6. kelompok A dengan dosis infusa daun sirsak $520 \mathrm{mg} / \mathrm{kg}$ BB nilai sig 0,191 $(p<0,05)$ ini berarti perlakuan pada kelompok $A$ sebelum dan sesudah perlakuan tidak terjadi perubahan secara signifikan meskipun secara rata-rata selisih perlakuan menunjukan jika kelompok A merupakan kelompok dengan rata-rata penurunan kadar kolesterol tertinggi di antara kelompok lainnya, selanjutnya pada kelompok B dengan dosis infusa daun sirsak $910 \mathrm{mg} / \mathrm{kg} \mathrm{BB}$ nilai sig $0,049(p<0,05)$ ini berarti perlakuan pada kelompok $B$ sebelum dan sesudah perlakuan memiliki pengaruh yang signifikan terhadap penurunan kadar kolesterol mencit, lalu pada kelompok $C$ dengan dosis infusa $1.690 \mathrm{mg} / \mathrm{kg}$ BB nilai sig 0,044 $(\mathrm{p}<0,05)$ menunjukan jika pada kelompok ini terjadi perubahan yang signifikan sebelum dan setelah pemberian perlakuan.

\section{Pembahasan}

Hasil skrining fitokimia menunjukan hasil positif untuk senyawa metabolit sekunder alkaloid, flavonoid, polifenol, dan tanin. Di beberapa jurnal di laporkan jika senyawa metabolit sekunder flavonoid mempunyai aktivitas biologis yang berperan dalam menurunkan kadar kolesterol. Flavonoid mampu mengurangi sintesis kolesterol dengan cara menghambat aktivitas enzim ACAT pada sel HepG2 yang berperan dalam penurunan esterifikasi kolesterol pada usus dan hati, serta menghambat aktivitas enzim 3-hidroksi-3-meti-glutaril-Coa yang menyebabkan penghambatan sintesis kolesterol. Flavonoid dalam daun sirsak berperan menurunkan penyerapan kolesterol dan asam epedu pada usus halus demi menginduksi peningkatan ekskresi fekal asam empedu dan steroid. Hal ini menyebabkan hati lebih banyak merubah kolesterol dalam tubuh menjadi empedu yang akibatnya dapat menurunkan kolesterol dan meningkatkan aktivitas reseptor kolesterol LDL, yang mengakibatkan peningkatan laju penurunan kadar kolesterol. Setiap hari, sekitar 1 gram kolesterol dikeluarkan dari tubuh. Sekitar separuhnya diekskresikan di dalam tinja setelah mengalami konversi menjadi asam empedu. Sisanya diekskresikan sebagai kolesterol (Prahastuti et al., 2011).

Adewole et al., (2006) menjelaskan bahwa ekstrak air daun sirsak (Annona muricata L.) dapat mengurangi peroksidasi lipid pada kasus tikus diabetes dengan induksi streptozotocin. Data yang diperoleh menunjukkan infusa daun sirsak berpengaruh terhadap penurunan kadar kolesterol mencit. Dari ketiga dosis infusa daun sirsak yang memiliki pengaruh terbesar dalam menurunkan kadar kolesterol yaitu dosis $520 \mathrm{mg} / \mathrm{kg}$ BB. Apabila dosis yang digunakan melebihi titik optimal dosis tersebut masih dapat menurukan kadar kolesterol namun efeknya lebih kecil. Tidak menutup kemungkinan bahwa dosis dibawah dosis $520 \mathrm{mg} / \mathrm{kg}$ BB memberikan efek penurunan kadar kolesterol yang lebih besar. Oleh karena itu perlu dilakuan variasi dosis lagi. Pada dosis $910 \mathrm{mg} / \mathrm{kg}$ 
BB terjadi penurunan kadar kolesterol meskipun tidak sebesar dosis I, akan tetapi secara statistika menggunakan uji T memberikan nilai yang signifikan, begitu pula dengan dosis $1.690 \mathrm{mg} / \mathrm{kg} \mathrm{BB}$.

\section{Kesimpulan}

Berikut adalah kesimpulan dari penelitian ini:

1. Pemberian infusa daun sirsak (Annona muricata L.) dengan dosis $520 \mathrm{mg} / \mathrm{kgBB}, 910$ $\mathrm{mg} / \mathrm{kgBB}$, dan $1.690 \mathrm{mg} / \mathrm{kgBB}$ dapat menurunkan kadar kolesterol mencit (Mus muculus) jantan galur swiss webster.

2. Dosis infusa daun sirsak $520 \mathrm{mg} / \mathrm{kgBB}$ menunjukan menurunkan rata-rata kadar kolesterol terbesar dibanding dosis lainnya.

\section{Referensi}

Adewole, S.O, and Ojewole, J.AO. 2006. Protective Effects Annona muricata Linn. (Annonaceae) Leaf Aqueous Extract on Serum Lipid Profiles and Oxidative Stress in Hepatocytes of Streptozotocin-Treated Diabetic Rats, African Journal of Biomedical Research, Vol.9, No.4: 173-180.

Kedari, Tai S., Khan, Ayesha A., 2014, Guyabano (Annona Muricata): A review of its Traditional uses Phytochemistry and Pharmacology, American Journal of Research Communication, 2(10): 247-268.

Prahastuti, Sijani, 2011, Konsumsi Fruktosa Berlebihan dapat Berdampak Buruk bagi Kesehatan Manusia. JKM.vol.10 No.2 Februari 2011

Sutanto, d., 2010, Cekal Penyakit Modern Hipertensi, Stroke, Jantung, Kolesterol, dan Diabetes, Yogyakarta, C.V ANDI OFFSET

Uneputty, Jonly Piere, Paulina V.Y. Yamlean, Novel Stien Kojong., 2013, Potensi Infusa Daun Sirsak (Annona muricata L.) Terhadap Kadar Kolesterol Darah Tikus Putih jantan ( Rattus novergicus), Jurnal IImiah Farmasi,Vol. 2,56-59.

Widyaningrum,Annisa, 2015, Pengaruh Perasan Daun Sambung Nyawa (gynura procumbens (Lour) Merr.) Terhadap Kadar Kolesterol Mencit (Mus musculus L.) dan Pemanfaatannya Sebagai Karya IImiah Populer, Skripsi, Program Studi Pendidikan Biologi Universitas Jember. 